\title{
Recipe for Russian Insulin
}

The share of locally produced insulin on the Russian market estimated at more than seven billion roubles in 2008 is, in reality, microscopic: national industry covers only $2 \%$ of the market (see Table 1). This is unreasonably small, especially because a) Russian producers have enough capacity to produce insulin for the entire country, with similar or even higher quality as compared with foreign products, b) hundreds of thousands of insulindependent patients in some particular political or economical circumstances could suffer without this life-saving treatment. The World Health Organization recommends that any country with a population of more than 50 millions have its own manufacturing base for insulin. Anatoly Miroshnikov is an assistant director of the M.M. Shemiakin and Y.A. Ovchinnikov' Institute of Bioorganic Chemistry of the RAS, which produces insulin with the trade name Insuran. He talks to Acta Naturae on why Russia needs its own factories for the production of genetically engineered drugs.

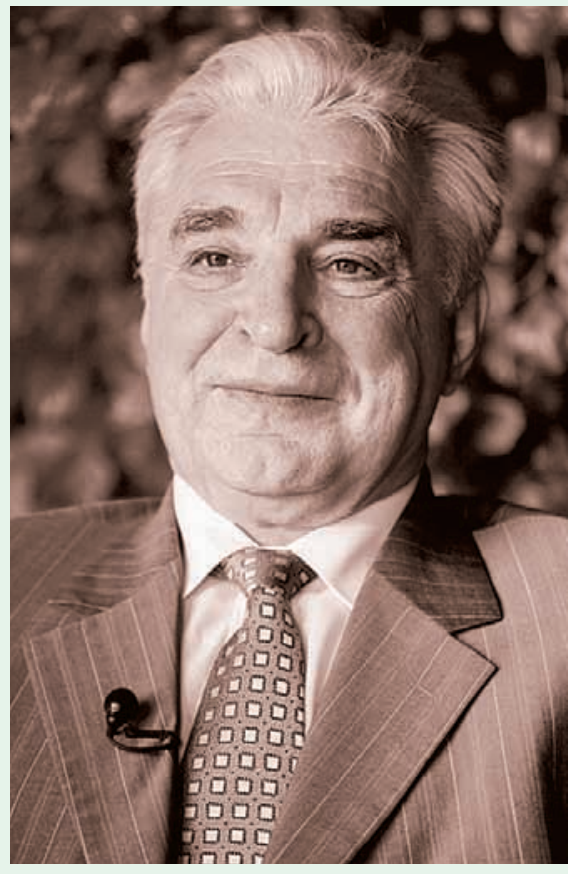

Anatoly Ivanovich Miroshnikov is full member of Russian Academy of Sciences, deputy director of the M.M. Shemiakin and Y.A. Ovchinnikov Institute of Bioorganic Chemistry of the RAS, president of the presidium of the Pushino Science Centre, vice-president of the Russian public organisation "Y.A. Ovchinnicov's Society of Biotechnologists of Russia."

and supplying short and form insulin to Moscow clinics 3 years later. According to Luzhkov's plan, we should have ramped up production to 300,000 phials a year. However, the city refused to buy such an amount of insulin: they argued that Moscow will slowly move away from phials insulin. Unfortunately, nobody gave us money for a cartridges production line. Now we are producing 95,000 phials a year and providing insulin to $15 \%$ of Moscow patients suffering from diabetes.

Have you had any reclamation on Insuran?

- Not one in the five years of manufacturing insulin. We produce it according the GMP standards, and each batch of 100 phials undergoes quality control. Chief endocrinologist of Mos- cow Michael Borisovich Amzyferov can testify to the quality of our insulin, and clinicians also agree that there is no difference between our insulin and Western-made insulin (Elly Lilly, Novo Nordisk). With the same quality, our "Insuran ${ }^{\circledR}$ " is cheaper. However, it is not easy to increase production, because the system for insulin supply to major clinics and pharmacies is already established and nobody likes new players. Long-established connections and, possibly, traditions of corruption play 
"Our medicine is not only cheaper but also better. In the production of Insurane, we do not use toxin bromocyan, but Elli Lilly still uses toxin, Novo Nordisk uses a cheap strain of yeast, which is less effective; now they are also switching to bacteria. However, all of this does not mean that a "green street" will be open for us. I am sure that we will have a lot of difficulties with the marketing of our product. Western companies will fight for a market like the Russian one. And they will try to brain-wash doctors that the quality of our insulin is worse. That means that principles of market competition will apply." From the interview of Anatoly Miroshnikov, 2000, "Meditsinskiy vestnik" v.4
Top 5 importers of the origin of insulin and its analogues, 1 st quarter of 2008.

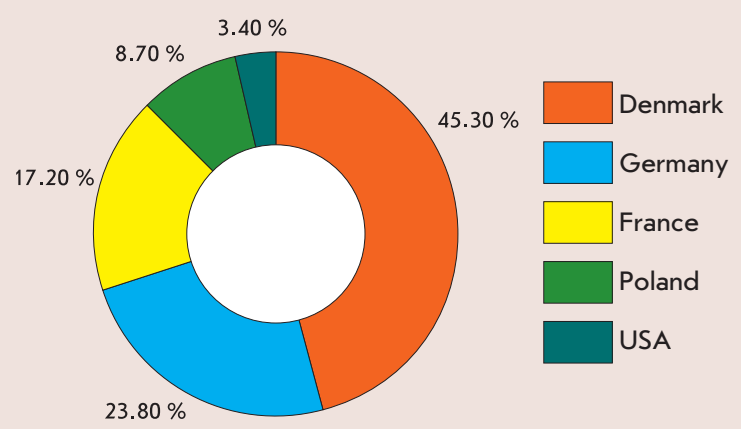

Centre for Marketing Research "Pharmexpert" a role... As a result, $90 \%$ of the Russian insulin market is in the hands of American and Danish companies. But we are not giving up: in the last 4 years, I have been struggling to build a factory in Pushino. The problem was almost solved: on an order of the government of the Moscow Region and the initiative of the RAS and IBC RAS, the joint stock company Bioran was created. The company should anchor the project of industrial design of medical genetically engineered drugs; we even had a plot and communications for this project. But, unfortunately, the financial crisis hit, and Bioran has struggled to secure a loan. If the state had provided a loan guarantee at that time, we would have had money. The factory should have started functioning in 4.5 years, and we would have repaid the loan in 8 years.

What volume of purchase did you have in mind?

- A full-cycle factory should have produced $400 \mathrm{~kg}$ of substance. That should have been enough for Russia, the Commonwealth of Independent States, and even for export to Arab countries and South East Asia.

Do I understand you correctly that your technology is not inferior to foreign technologies?

- I can say that our technology is even better!

\section{INSTRUCTIONS FOR USE.}

- Does it mean that this question is economical and political?
Absolutely! And we try to explain it to our executive branch. In a letter to Igor Sechin, deputy prime minister, I indicated that, if we want to rebuild our pharmaceutical industry, we need to build at least 2 factories: one must be in chemistry and pharmacy and one for genetically engineered drugs production (there are about 40 factories

of the type in the world). I believe that the only location for a factory for the production of genetically engineered drugs is Pushino. Pushino has everything needed for the development of a bio-pharmaceutical industry: 7 specialized research institutes in physical and chemical biology, two universities, and experimental research facilities with in-

Table 1

\begin{tabular}{|c|c|c|}
\hline Company-producer & 2008 y., roubles. & 2008 y., roubles \% \\
\hline Novo Nordisk & 3402384126 & 47.39 \\
\hline Sanofi-Aventis & 1720706535 & 23.97 \\
\hline Elli Lilly & 1760622611 & 1.81 \\
\hline $\begin{array}{c}\text { MARVEL LIFESCIENCE S PVT.Ltd } \\
\text { Mvin Shemiakin and YA } \\
\text { Chov'snstitute of Bio-organic }\end{array}$ & 129616186 \\
\hline BIOTON S.A. & 74424660 & 0.36 \\
\hline Pharmstandart Llc & 25986679 & 0.37 \\
\hline TONGHUA DONGBAO & 26651492 & 0.04 \\
\hline PHARMACEUT ICAL CO.Ltd & 2695064 & 0.38 \\
\hline others & 27136365 & 0.13 \\
\hline M.J.BIOPHARM & 9081318 & 0.00 \\
\hline "Brynzalov-A" Ltd & 40667 & 0.00 \\
\hline Tazionalnye Biotechnologii Plc & 30979 & \\
\hline
\end{tabular}




\section{REFERENCE:}

The Shemyakin and Ovchinnikov Institute of Bioorganic Chemistry already has ready-for-introduction developments of human albumin, some blood factors and enzymes based on which it is possible to develop anti-viral and anti-tumour drugs. Also, scientists from the institute have developed a new analogue of insulin, which has a quicker and long-term effect. Already on the market are the first Russian-produced insulin and growth hormone.

ternational certificates. It is possible to produce insulin, interferon, blood factors, and other drugs there. There was a time when our chemical-pharmaceutics factories ranked $5^{\text {th }}$ in the World behind the US, Germany, Japan, and France. Today we import around $85 \%$ of our drugs and we produce around $12 \%$ of the drugs we need from foreign raw materials. At the same time, the majority of clinical trials of western drugs take place in Russia. Yes, in the 1990s, when, for example, oncological centers gained access to western drugs in this way, it was possibly a reasonable policy. But why they use us only as a testing ground? It is not obvious that all clinical trials will be successful. And they conduct experiments on people.

- So... What do we have to do if we want to wean ourselves off imported insulin?

Firstly, our government should decide about building at least two fac- tories, and state corporations such as Rosnano or Rostechnologii should be responsible for the realisation of this plan. It is nonsense to believe that private capital will invest money into factory-building projects. However, it will be possible to sell this factory to a private Russian company after completion. Bioran can build this factory, and I deeply believe that Bioran should give $50 \%$ plus 1 share to the state or a state corporation.

Second, I believe that we need to talk not only about the development of the pharmaceutical industry, but also and even more about the development of dependent import-substitution. If RAMS will unveil the list of the 2,000 most wanted drugs for the cure of onco-, cardio-, and pulmonary diseases and others to scientists, the scientists will quickly find a way to avoid patenting problems! However, the next step - experimental production - will be re- quired. One of the very few biotechnological manufacturing site in Russia is at our institute.

\section{CONTERINDICATION TO IMPORT}

Today almost $70 \%$ of the drugs produced in Russia are non-innovative drugs. Should we also produce raw materials or it would be easier to buy them? What do you think?

- To produce! Definitely to produce! At least, the control of production should be on the National level, - it is the security of the country. It is possible that Russia needs a big disaster to understand that we need our own pharmaceutical industry with a full cycle of production of at least the most important drugs. Imagine that one day the import of insulin from abroad is stopped - that means that the lives of the hundreds of thousands of diabetics will be in danger! It seems that that will never happen. But we already have lessons of that kind. We started to develop the 7-th blood factor, which is involved in blood clotting, only after the Beslan tragedy. Director of the Science Centre of Haematology of RAMS Andrei Ivanovich Vorobiev told me that we lost a lot of lives because of the absence of this drug. Russia imports it from Danmark, it is very expensive, and we buy it in small quantities; in case of an emergency, we simply do not have enough of it. The situation with insulin, as you see, is similar... 


\section{INNOVATIVE RUSSIA}

discussion club

We form a dialogue between students, scholars, teachers, businessmen, managers, innovators, investors, designers, art historians, architects, photographers - all socially active people.

\section{Find more at WWW.STRF.RU}

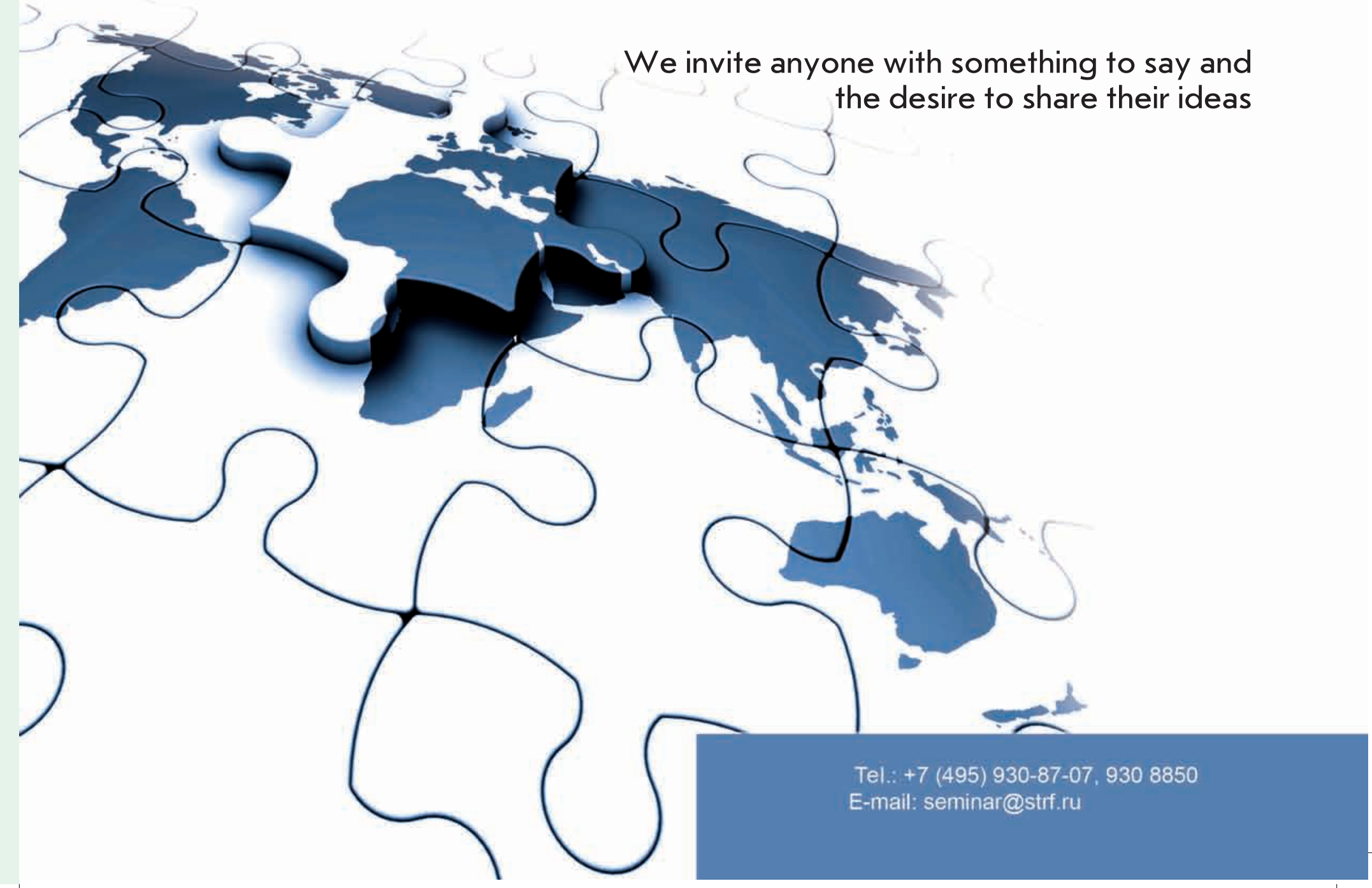

